\title{
PENOLAKAN TERHADAP NARASI BESAR DALAM NOVEL NEGARA KELIMA KARYA E.S. ITO (TINJAUAN DEKONSTRUKSI JACQUES DERRIDA)
}

\author{
Nurwahidin NL., Muhammad Rapi, dan Hajrah \\ Fakultas Bahasa dan Sastra, Universitas Negeri Makassar \\ Jalan Daeng Tata Raya, Kampus Parangtambung UNM, Makassar \\ Email: didin.sastra@rocketmail.com.
}

\begin{abstract}
The rejection on Big narration in Negara kelima's novel by E.S. Ito (Jacques Derrida's deconstruction analysis)". The aim of this research is to describe the rejection of big naration text in Negara Kelima novel by E.S. Ito by using Jacques Derrida's deconstruction analysis. This research is descriptive qualitative research. The source of the data is the Negara Kelima novel by E.S. Ito which is published by Serambi Ilmu Semesta. Then, the data is gained from the text in Negara Kelima novel by E.S. Ito which is a rejection on Big Narration according to Jacquess Derrida. The instrument of the research is self-research under the idea and knowledge about research by using Library research, the researcher understand, identify, analyze, then, describe based on the deconstruction theory from Jacques Derrida. The result of the research shows to us that E.S. Ito conducted a rejection on three big narration, the first one about science narration in terms of reading maps (Cartograf), in reading modern map, decosntruction allow the reader to do reverse reading in finding Ancient history. The second is about Religion narration (Islam), E.S Ito deconstruct the moeslem's society paradigm about the existence of heaven, and the third is about history narration.
\end{abstract}

\begin{abstract}
Abstrak. "Penolakan terhadap Narasi Besar dalam Novel Negara Kelima Karya E.S. Ito (Tinjauan Dekonstruksi Jacques Derrida)". Penelitian ini bertujuan untuk mendeskripsikan teks-teks penolakan narasi besar dalam novel Negara Kelima karya E.S. Ito menggunakan tinjauan dekonstruksi dari Jacques Derrida. Penelitian ini termasuk penelitian deskriptif kualitatif. Sumber data dalam penelitian ini adalah novel Negara Kelima karya E.S. Ito yang diterbitkan oleh Serambi Ilmu Semesta. Adapun yang menjadi data dalam penelitian ini adalah teks-teks yang terdapat dalam novel Negara Kelima karya E.S. Ito.yang merupakan penolakan terhadap narasi besar menurut teori Jacques Derrida. Instrumen pengumpulan data adalah peneliti sendiri dengan gagasan serta pengetahuan tentang kajian penelitian dengan teknik kepustakaan, yaitu peneliti memahami, mengidentifikasi, menganalisis kemudian mendeskripsikan berdasarkan teori dekonstruksi dari Jacques Derrida. Hasil penelitian ini menunjukkan bahwa E.S. Ito melakukan penolakan pada tiga narasi besar yaitu pertama mengenai narasi keilmuan (kartografi) dalam hal pembacaan peta, Dalam membaca peta modern, dekonstruksi memungkinkan pembaca untuk melakukan pembacaan terbalik untuk menemukan sejarah kuno. Kedua mengenai narasi agama (Islam), E.S. Ito membongkar pemahaman masyarakat muslim tentang keberadaan surga, dan Ketiga mengenai narasi sejarah.
\end{abstract}

Kata kunci: dekonstruksi, narasi besar, penolakan

Kebebasan seorang pengarang dalam berkarya berhubungan dengan ekspresi dan penciptaan narasi yang tentu saja bersifat subjektif. Mengenai batasan sastra, ada baiknya dibebankan dalam kegiatan keilmuan. Hal inilah yang membuat semua ahli sastra sepakat untuk tidak gegabah memberikan definisi sastra.
Sebagaimana ditegaskan oleh Jakob Sumardjo dalam Apresiasi Kesusastraan, sastra merupakan gagasan pengarang yang berusaha diinterpretasikan ke dalam suatu bentuk. Dalam hal ini, berupa teks-teks kebahasaan, yang digunakan sebagai sudut pandang subjektif pengarang. 
Di sisi lain, pembaca juga memiliki kebebasan dalam menginterpretasikan karya sastra. Sebagai contoh dalam roman Siti Nurbaya, tokoh Datu Maringgi digambarkan sebagai tokoh antagonis, sementara Syamsul Bachri digambarkan lebih superior. Pembaca yang bebas, bisa saja menginterpretasikan bahwa Datu Maringgi sebagai sosok yang luar biasa dengan sosok nasionalismenya yang tak mau patuh pada kolonial. Sementara sosok Syamsul Bachri dianggap sebagai sosok yang cengeng dan pengecut dengan menjadi salah satu antekantek kolonial untuk balas dendam dan pengganggu istri orang lain.

Pembacaan demikian tentu saja memunculkan kesenjangan antara gagasan pengarang dengan interpretasi pembaca. Dengan demikian, dalam membaca karya sastra ada hal penting yang perlu diketahui yakni gagasan pengarang dan interpretasi pembaca. Pembacaan tersebut merupakan salah satu tinjauan dalam menganalisis karya sastra utamanya dalam teksteks yang dibangun oleh pengarang yang selanjutnya disebut analisis tinjauan dekonstruksi. Analisis inilah yang akan peneliti gunakan sebagai metode dalam penelitian ini.

Peneliti menggunakan novel Negara Kelima dalam penelitian ini. Negara Kelima bercerita tentang pemecahan teka-teki oleh tokoh utama Timur Mangkuto. Timur adalah seorang polisi yang menjadi buron karena dituduh membunuh seorang Inspektur Satu Rudi Djatmiko sekaligus sebagai salah satu anggota teroris yang bernama KePaRad (Kelompok Patriotik Radikal).

Pemecahan teka-teki mengenai negara kelima muncul ketika wacana pembubaran negara Indonesia dan pembentukan negara kelima didengungkan oleh KePaRad. Timur Mangkuto harus berpacu dengan waktu untuk memecahkan teka-teki itu agar namanya bisa dibersihkan dari tuduhan yang ditujukan padanya. Sementara itu, Timur Mangkuto dalam pelariannya dibantu oleh rekan kerjanya bernama Genta dan bertemu dengan Eva Duani seorang sejarawati.

Teka-teki tersebut mengarah pada kejayaan Atlantis, sebuah pulau dengan peradaban tinggi yang tenggelam hanya dalam waktu semalam akibat banjir besar. Menurut $\mathrm{KePaRad}$, inilah negara pertama. Negara kedua, ketiga, dan keempat mengarah pada beberapa peristiwa sejarah Indonesia. E.S. Ito menggunakan beberapa peristiwa dunia untuk menghubungkan Atlantis dengan Indonesia, termasuk penaklukan besar-besaran yang dilakukan oleh Alexander the Great.

Tidak mudah membawa peristiwa sejarah yang menjadi narasi konvensional dengan kebenaran cenderung mutlak kedalam sebuah cerita fiksi. Betapa tidak, seorang pengarang harus mengacu pada data fakta sejarah. Namun, E.S. Ito piawai memainkan alur hingga tidak sekedar menyediakan data sejarah, melainkan juga membalik bahkan menggembosi data tersebut. Hal inilah yang membuat peneliti tertarik menganalisis novel Negara Kelima karya E.S. Ito menggunakan tinjauan dekonstruksi.

Penelitian yang relevan dengan penelitian ini adalah penelitian yang dilakukan oleh Mahmudi Arif dengan judul "Analisis Dekonstruksi dalam Novel Cala Ibi Karya Nukila Amal.”.

Penelitian Mahmudi Arif tersebut menjadi satu-satunya penelitian yang relevan dengan penelitian ini. Persamaannya terletak pada teori yang digunakan yaitu teori dekonstruksi Derrida. Hanya saja peneliti sebelumnya menitikberatkan pada oposisioposisi biner yang diistimewakan oleh pengarang sedangkan peneliti kali ini akan menganalisis bentuk teks penolakan terhadap narasi besar dalam novel Negara Kelima yang menjadi objek kajian penulis.

\section{METODE PENELITIAN}

Metode yang dimaksud dalam penelitian ini adalah hal yang berkaitan dengan cara kerja dalam mendapatkan data sampai menarik kesimpulan. Penelitian ini merupakan penelitian kepustakaan yang bersifat deskriptif kualitatif. Masalah yang akan diangkat adalah tinjauan teks dekonstruksi dalam menggembosi narasi besar pada novel Negara Kelima karya E.S. Ito.

Menurut jenisnya, penelitian ini adalah penelitian kualitatif. Oleh karena itu, dalam penyusunan desain harus dirancang berdasarkan prinsip metode deskriptif kualitatif, yaitu mengumpulkan, mengolah, mereduksi, menganalisis dan menyajikan data secara objektif atau sesuai dengan kenyataan yang ada di lapangan untuk memperoleh data. Untuk itu, peneliti dalam menjaring data akan mendeskripsikan pembedahan teks novel Negara 
Kelima karya E.S. Ito dengan metode dekonstruksi.

Adapun data dalam penelitian ini adalah teks kutipan atau pernyataan yang mengandung unsur dekontruktif mengenai penolakan narasi besar yang terdapat dalam novel Negara Kelima karya E.S. Ito sesuai dengan teori dekonstruksi. Sedangkan sumber data yang digunaakan dalam penelitian ini yaitu data yang diperoleh dari teks novel Negara Kelima karya E.S. Ito. Prosedur pengambilan data dari sumber data ini, ditempuh dengan cara mengambil kutipan-kutipan tertentu dari teks novel yang dikaji. Kemudian data tersebut dipergunakan sebagai bahan penelitian yang akan dianalisis.

Dalam penelitian ini, langkah awal yang ditempuh ialah peneliti terlebih dahulu membaca teori dekonstruksi dari Derrida, selanjutnya membaca novel Negara Kelima karya E.S. Ito yang menjadi objek dalam penelitian ini, kemudian membuat sinopsis dari novel tersebut. Pengumpulan data dalam penelitian ini ditempuh dengan melakukan penelitian kepustakaan yaitu teknik dokumentasi, teknik baca dan teknik pencatatan.

Setelah seluruh data terkumpul, maka langkah selanjutnya adalah menganalisis data. Teknik analisis data dilakukan dengan mengidentifikasi teks yang mengandung muatan dekonstruksi yakni penolakan terhadap narasi besar dalam novel Negara Kelima karya E.S. Ito, mengklasifikasi teks yang mengandung muatan dekonstruksi yakni penolakan terhadap narasi besar dalam novel Negara Kelima karya E.S. Ito., menganalisis teks yang mengandung muatan dekonstruksi yakni penolakan terhadap narasi besar dalam novel Negara Kelima karya E.S. Ito., dan mendeskripsikan teks yang mengandung muatan dekonstruksi yakni penolakan terhadap narasi besar dalam novel Negara Kelima karya E.S. Ito.

\section{Pembahasan Hasil Penelitian}

Menurut Derrida (dalam Aminuddin. 2002: 170), Dekonstruksi membuka jalan dalam aktivitas berfikir dan penandaan dalam proses penjejakan jaringan makna guna membentuk pemahaman. Bagi Derrida, dekonstruksi juga merupakan writing, dalam arti bukan hanya mengacu pada writing sebagai bentuk performatif, melainkan juga sebagai proses penyusunan pengertian, penyusunan pemahaman, dan pembentukan proposisi yang berlangsung secara terus menerus dalam aktifitas berfikir. Dengan kata lain, dekonstruksi bukan berupa teknik atau metode. Dekonstruksi juga bukan merupakan kesenangan sesaat buat keluar dari kungkungan kegelapan makna, tetapi merupakan upaya yang dalam untuk mengatasi keterbatasan pemahaman gambaran makna. Sebagai proses penyusunan pemahaman yang ditandai oleh adanya redubling (pengulangan) dekonstruksi bermula dari metafisika oposisi binnear. Pada langkah tersebut pembaca berusaha menemukan oposisi maupun kontradiksi.

Selain itu, anggapan lain tentang dekonstruksi adalah teori yang membuka diri untuk ditafsirkan oleh siapapun lantaran dimensinya yang amatlah luas. Setiap upaya untuk mendefinisikan dekonstruksi akan terbentur, karena Derrida sendiri menolak membatasi pengertian dekonstruksi dalam satu definisi. Dekonstruksi adalah strategi tekstual yang hanya bisa diterapkan langsung jika kita membaca teks lalu mempermainkannya dalam parodi-parodi. Lebih jauh bisa dikatakan bahwa dekonstruksi bersifat anti teori atau bahkan anti metode, karena yang menjadi analisis di dalamnya adalah permainan (play) dan parodi.

Sebuah teks selalu memiliki wajah ganda. Ketika kita berfikir mengenai sebuah makna dan menarik kesimpulan dari makna tersebut, sering kali di saat itulah teks menorehkan makna lain yang berbeda dari makna yang telah kita ambil. Makna itu sering kali tidak terpikirkan karena mungkin merupakan makna sekunder yang tidak dikehendaki oleh pengarang. Akan tetapi, keberadaan makna itu sudah membuktikan bahwa pemahaman kita terhadap sebuah teks tidak pernah tunggal dan menyimpan potensi penafsiran baru yang kerap kali tak terduga. Penampakan sebuah teks tidak sedatar penampang permukaannya. Pengertianpengertian teks juga tidak sebatas pada pemaknaan denotatif yang ingin menangkap makna tersurat, tapi juga pemaknaan konotatif yang tak tersurat, atau logika yang dengan sengaja disembunyikan dibalik teks. Dekonstruksi Derrida adalah sebentuk upaya untuk memberdayakan pemaknaan tersiratlogika yang cenderung dilupakan atau diparkir karena prioritas dan pilihan tertentu dari sebuah teks (Al-fayyadl, 2011:78) 
Pembacaan Karya Sastra menurut paham Dekonstruksi, tidak dimaksudkan untuk menegaskan makna sebagaimana yang lazim dilakukan. Sebab, sekali lagi tak ada makna yang dihadirkan oleh suatu yang sudah menentu. Melainkan justru untuk menemukan makna kontradiktifnya, makna ironisnya. Pendekatan dekonstruksi bermaksud untuk melacak unsur Aporia, yaitu yang berupa makna paradoksal, makna kontradiktif, makna ironi, dalam Karya Sastra yang dibaca. Unsur dan bentuk-bentuk dalam karya itu dicari dan dipahami justru dalam arti kebalikannya. Unsur-unsur yang tidak penting dilacak dan kemudian dipentingkan, diberi makna, peran, sehingga akan terlihat (atau: menonjol) peranannya dalam karya yang bersangkutan. Misalnya seorang tokoh cerita yang tidak penting berhubungan hanya sebagai tokoh peripheral, tokoh kelompok pinggiran saja, setelah didekonstruksi ia menjadi tokoh yang penting, yang memiliki fungsi dan makna yang menonjol sehingga tak dapat ditinggalkan begitu saja dalam memaknai karya itu (Nurgiantoro, 2010: 61).

Muatan-muatan teori dekonstruksi ketika di kontekskan dengan Novel Negara Kelima karya E.S. Ito, telah kita bagi dalam pembahasan sebelumnya. Namun akan kita bahas lebih lanjut tentang korelasi antara teori dan objek.

Berdasarkan analisis yang dilakukan menggunakan dekonstruksi pada novel Negara Kelima, ditemukan tiga narasi yang didekonstruksi oleh pengarang. Pertama adalah narasi keilmuan dalam hal ini kartografi mengenai pembacaan arah mata angin pada peta. Menurut ilmu kartografi, secara konvensional dalam membaca arah mata angin bisa dilihat pada simbol kompas yang terletak di sudut media peta. Posisinya bisa saja berada di sudut kiri atau kanan atas media peta, bisa juga berada di sudut kiri atau kanan bawah. Simbol kompas tersebut selalu menunjukkan arah utara pada bagian atas peta, baik itu media kertas maupun digital.

Kedua adalah narasi agama (Islam) mengenai keberadaan surga Adam. Menurut Islam, Nabi Adam adalah manusia pertama yang diciptakan dari segumpal tanah kemudian dibentuk menjadi manusia dan ditiupkan roh oleh Tuhan. Setelah Nabi Adam hidup, dia mendiami surga dengan segala kebutuhan ada di dalamnya. Oleh karena Nabi Adam melakukan sebuah kesalahan, maka dia diusir dari surga dan diturunkan ke bumi.

Keberadaan surga yang ada di langit adalah sesuatu yang harus diyakini seorang muslim tanpa memerlukan logika. Kebenarannya adalah sebuah kemutlakan.

Ketiga adalah narasi sejarah mengenai perjalanan kemerdekaan negara Indonesia. Indonesia merdeka tahun 1945 dan bertahan lebih dari 60 tahun hingga saat ini. Sejarahnya dituliskan dan wajib dipelajari di bangku sekolah sejak tingkatan dasar hingga tingkat atas.

Langkah identifikasi yang dilakukan sesuai dengan yang telah disebutkan oleh Derrida (dalam Norris. 2008: 13) mengidentifikasi hierarki oposisi dalam teks, dimana biasanya dapat terlihat peristilahan mana yang diistimewakan secara sistematis dan yang mana yang tidak. Dalam novel Negara Kelima, pengarang memunculkan narasi-narasi yang menjadi oposisi dari narasi yang diistimewakan oleh publik melalui keilmuan, agama, dan sejarah.

Langkah mengidentifikasi hierarki oposisi sebenarnya dapat lakukan dengan pembacaan yang biasa, karena dalam pembacaan normal kita akan diarahkan untuk menyimpulkan sebuah makna tunggal. Pada tahapan ini sekilas terlihat mudah, akan tetapi inti dekonstruksi tidaklah terletak pada tahapan ini, melainkan pada tahapan identifikasi hierarki oposisi ini merupakan awal dari pembongkaran teks secara mendalam dengan maksud untuk menggali potensi makna yang tidak disadari oleh pengarang atau bahkan sengaja untuk ditutupi.

Menurut Derrida (dalam Faruk. 2012: 214). Oposisi berpasangan merepresentasikan sebuah cara melihat yang bersifat ideologis. Ideologi-ideologi seringkali menggambarkan batas-batas yang kaku antara apa yang dapat diterima dan apa yang tidak, antara kebenaran dan kepalsuan, yang masuk akal dan yang tidak masuk akal. Derrida menyarankan agar kritikus berusaha merontokkan oposisi-oposisi yang dengannya orang sudah terbiasa untuk berfikir dan yang menjamin bertahan hidupnya metafisika dalam fikiran orang. Dengan menggunakan metode dekonstruksi, kritikus dapat mengurai atau mempreteli oposisi-oposisi itu. Menunjukkan bagaimana satu term sebenarnya terimplikasikan, inheren di dalam term lain. 
Mengondisikan pandangan Derrida pada Novel yang menjadi objek kajian, kita dapat melihat representasi cara melihat yang bersifat ideologis yang ditunjukkan oleh pengarang dengan membuat apa yang tidak masuk akal selama ini menjadi masuk akal.

Pertama yaitu memungkinkannya pembalikan arah mata angin pada peta untuk menelusuri sejarah Atlantis dan meruntuhkan hegemoni superior barat terhadap timur. Pengarang menunjukkan bahwa sejarah yang selama ini diketahui sarat dengan muatan politik untuk kepentingan kalangan tertentu. Sehingga interpratasi baru mengenai alur sejarah dalam melacak Atlantis melalui napaktilas penduduk asli setempat ditonjolkan.

Pengarang berhasil melakukan penolakan terhadap narasi keilmuan mengenai pembacaan peta. Arah utara yang selama ini dikenal secara konvensional dibalik menjadi selatan. Alur serta alasan mengapa arah mata angin pada peta itu terbalik menjadi rasional sehingga oposisi antara fakta dan fiksi menjadi kabur dan saling terhubung.

Selanjutnya yang kedua adalah penggambaran oposisi antara dogma agama Islam dengan pemikiran logis seseorang tentang surga. Surga identik dengan sebuah tempat metafisis yang dulu menjadi tempat tinggal nabi Adam sebelum di turunkan ke bumi menurut Islam. Sedangkan tokoh Duani Abdullah dalam Negara Kelima lebih percaya pada teori bahwa surga tersebut bukanlah sebuah tempat metafisis melainkan sebuah tempat yang faktual dan ada di Bumi.

Pada dasarnya, narasi tentang agama sangatlah sensitif untuk dianalisis karena bersentuhan dengan keyakinan yang kadang tidak butuh rasionalitas dan sangat bertolak belakang dengan logika. Akan tetapi disinilah sesungguhnya peran dekonstruksi yang hadir untuk memggemparkan keyakinan atas makna tunggal. Surga yang dipercaya oleh Islam berada di langit kemudian ditolak dan secara logika pengarang menyebutkan bahwa surga ada di bumi. Penolakan narasi agama Islam dalam novel Negara Kelima menjadi rasional dengan tautan sejarah secara diakronik.

Terakhir adalah sejarah versi penguasa yang beroposisi dengan sejarah versi rakyat.

Negara Kelima menampilkan sudut pandang lain dalam menilai sejarah nasional Indonesia. Ketidakpuasan terhadap Jawasentris membuat
E.S. Ito menampilkan wajah sejarah Indonesia dari sudut pandang Minangkabau. Kemudian persoalan prinsip mengenai usia Indonesia, yang tidak mencapai 60 tahun dalam pandangan landasan integrasi ide dan gagasan.

Beberapa hal yang telah disebutkan diatas telah menunjukkan bahwa setiap oposisi menunjukkan adanya saling ketergantungan satu dengan yang lainnya. Pembalikan hierarki oposisi menurut Derrida (dalam Norris. 2008:14) Oposisi-oposisi itu dibalik, dengan menunjukkan adanya saling ketergantungan diantara yang saling bertentangan.

Inti dari dekonstruksi terletak pada tahapan ini, dimana proses kerja yang telah dilakukan telah mengarah pada hasil yang di inginkan. Menurut Nurgiantoro (1994: 61). Pembacaan Karya Sastra menurut paham Dekonstruksi, tidak dimaksudkan untuk menegaskan makna sebagaimana yang lazim dilakukan. Sebab, sekali lagi tak ada makna yang dihadirkan oleh suatu yang sudah menentu. Melainkan justru untuk menemukan makna kontradiktifnya, makna ironisnya. Pendekatan dekonstruksi bermaksud untuk melacak unsur Aporia, yaitu yang berupa makna paradoksal, makna kontradiktif, makna ironi, dalam Karya Sastra yang dibaca. Unsur dan bentuk-bentuk dalam karya itu dicari dan dipahami justru dalam arti kebalikannya. Unsur-unsur yang tidak penting dilacak dan kemudian dipentingkan, diberi makna, peran, sehingga akan terlihat (atau: menonjol) peranannya dalam karya yang bersangkutan.

\section{KESIMPULAN}

Dekonstruksi merupakan salah satu cara untuk membuka cakrawala berfikir secara kritis. Kebenaran secara absolut tidak diharapkan dalam teori dekonstruksi sehingga memungkinkan adanya sikap baru dalam memandang suatu wacana.

Sedikitnya ada tiga penolakan terhadap narasi besar yang peneliti analisis dari novel Negara Kelima karya E.S. Ito, yakni pertama mengenai narasi keilmuan (kartografi) dalam hal pembacaan peta. Dalam membaca peta modern, dekonstruksi memungkinkan pembaca untuk melakukan pembacaan terbalik untuk menemukan sejarah kuno. 
Kedua mengenai narasi agama (Islam), E.S. Ito membongkar pemahaman masyarakat muslim tentang keberadaan surga. Surga yang menurut pandangan Islam berada di tempat di luar bumi berhasil di ubah oleh pengarang menurut persepsinya yang percaya bahwa surga ada di bumi.

\section{DAFTAR PUSTAKA}

Al-Fayyadl, Muhammad. 2011. Derrida (Edisi khusus komunitas). Yogyakarta: PT. LKIS Printing Cemerlang.

Aminuddin. Dkk. 2002. Analisis Wacana; Dari Linguistik Sampai Dekonstruksi. Yogyakarta. Penerbit Kanal.

Anwar, Ahyar. 2008. Pengantar Sastra. Bahan Kuliah. Makassar: FBS UNM.

Arif, Mahmudi. 2013. Analisis Dekonstruksi Dalam Novel "Calla Ibi" Karya Nukila Amal. Skripsi. Makassar: FBS UNM.

Endraswara, Suwardi. 2003. Metodologi Penelitian Sastra. Yogyakarta: MedPress.

Faruk. 1994. Pengantar Sosiologi Sastra. Yogyakarta: Pustaka Pelajar.

Faruk. 2012. Metode Penelitian Sastra. Yogyakarta: Pustaka Pelajar

http://id.wikipedia.org/wiki/Dekonstruksi. diakses 139-2013. 15:35.

http://rumahfilsafat.com/2009/11/29/derrida-dandekonstruksi/ diakses 13-9-2013. 15:41.

Ito, E.S. 2008. Negara Kelima. Jakarta: PT. Serambi Ilmu Semesta.

Laelasari dan Nurlaila. 2008. Kamus istilah sastra. Bandung: Nuansa Aulia.
Ketiga mengenai narasi sejarah. Pengarang menunjukkan hegemoni jawa terhadap pulau lain dalam konstruksi sejarah Indonesia. Kemudian pengarang menonjolkan versi sejarah dari daerah lain.

Luxemburg Dkk. 1984. Pengantar Ilmu Sastra. Jakarta: PT Gramedia.

Muzir, inyiak Ridwan. 2008. Membongkar Teori Dekonstruksi Jacques Derrida (diterjemahkan dari: deconstruction; practice and theory karya Crisstopper Norris). Jokjakarta. Ar-ruzz Media.

Nurgiantoro, Burhan. 2010. Teori Pengkajian Fiksi. Yogyakarta: Gajahmada University press.

Ratna, Nyoman Khuta, 2004. Teori, Metode, dan Teknik Penelitian Sastra. Yogyakarta: Pustaka pelajar.

Sarup, Madan. 2003. Posstrukturalisme dan Posmoderenisme. Yogyakarta: Penerbit Jendela.

Stanton, Robert. 2007. Teori fiksi. Yogyakarta: Pustaka pelajar.

Sumardjo, Jacob dan Zaini KM. 1986. Apresiasi Kesusastraan. Jakarta: Gramedia

Susanto, Dwi. 2012. Pengantar Teori Sastra. Jakarta: Caps.

Tarigan, Hendry Guntur. 2011. Prinsip-Prinsip Dasar Sastra. Bandung: Angkasa.

Todorov, Tzevetan. 1985. Tata Sastra. Jakarta: Djambatan.

Wellek, Rene \& Austin Werren. 1995. Teori Kesusastraan. Jakarta: PT. Gramedia Pusat Utama. 